\title{
Developing the Virtuous Self in an Online MBA: Reflections on Instruments and Processes
}

\author{
Valerie Dalton ${ }^{1}$, Bligh Grant $^{2}$, Theresa Smith-Ruig ${ }^{1} \&$ Kay Hempsall ${ }^{1}$ \\ ${ }^{1}$ UNE Business School, University of New England, Armidale, NSW Australia \\ ${ }^{2}$ Centre for Local Government, University of Technology Sydney, Australia \\ Correspondence: Bligh Grant, UNE Business School, Centre for Local Government, University of Technology \\ Sydney, Australia. E-mail: Bligh.Grant@uts.edu.au
}

Received: July 13, 2015

Accepted: August 20, 2015

Online Published: September 18, 2015

doi:10.5539/ijbm.v10n10p1

URL: http://dx.doi.org/10.5539/ijbm.v10n10p1

\begin{abstract}
The relationship between virtue ethics and leadership is profound and has been the subject of sustained examination (see, for example, Fontrodona et al., 2012). The core of these debates has centred on the way in which a life of the good, conceived as a process of self-awareness built through experience and reflection, has the capacity to comprise the people who inhabit, lead, and constitute organizations. Prima facie management education ought to entail the explicit development of the virtuous self, rather than this being a residual element to overall education. This requires a more reflective approach to management teaching practice. We are challenged in this endeavour by our status as providers of online education. Our central concern in this paper is to provide an account of a Leadership Development ePortfolio, particularly its development to a program of online leadership skill development. This includes, among other skills, the development of reflective practice skills, development of self-awareness, self-mastery (Senge, 1990), and a consideration of how to apply those skills to others (e.g.: mentoring) and with others (e.g., team learning, service learning). We argue that introducing these elements to a program fosters the development of ethically virtuous management graduates.
\end{abstract}

Keywords: business ethics, ethical leadership, sustainability, virtue ethics

\section{Introduction}

In 2010 the United Nations (UN) put forward its 'Principles of Responsible Management Education' (PRME) stating that business school students need a greater grounding in the understanding and development of professional ethical practice. In particular, the UN argued that sustainability and corporate social responsibility (CSR) have become 'business critical' because of the gravity of recent crises (UN, 2010; see also Blasco, 2012; Waples et al., 2009). This paper addresses the growing focus on ethics in business education, as well as the tension between what we choose to denote as the 'textbook' characterization of ethical theorising on the one hand and more advanced understandings of these ideas on the other. We argue that a resurgent, sophisticated and authentic ethical awareness can be fostered through the use of the online space and other forms of technology for facilitating such techniques. For the purposes of this argument, we adopt the concise definition of ethics offered by Michel Foucault (1997, p. 294) namely, that: 'Freedom is the ontological condition of ethics. But ethics is the considered form that freedom takes when it is informed by reflection'. The tool through which we explore such reflection is a Leadership Development ePortfolio (LDE) undertaken as part of an online MBA Program.

An ePortfolio or electronic portfolio is a 'digital collection of authentic and diverse evidence, drawn from a larger archive, that represents what a person has learned over time, on which the person has reflected, designed for presentation to one or more audiences for a particular rhetorical purposes' (Cambridge, 2008, p. 245). ePortfolios can be oriented toward recording artefacts for formal assessment (see, for example, Woodley \& Simms, 2011). Alternatively, they can take a more formative approach and encourage reflection on the learning process, knowledge acquired and how that knowledge will improve the learning journey (Rossi, Magnoler, \& Giannandrea, 2008). We argue that there is value in drawing on the life and work experience of MBA students to encourage deeper engagement in their learning within and across the curriculum to enhance self-knowledge and character development.

The paper is divided into six main parts. Section two addresses the notion of virtue ethics and its role in leadership education. Section three reviews the management education literature, observing that there has been a 
tendency to discuss the importance of virtue ethics, but in a nascent way. Section four provides an account of a particular online leadership development program that the authors have developed as an element to an MBA program, focusing on the development of what we are denoting as 'the virtuous virtual self'. Section five counters criticisms of programs such as this by a consideration of recent discussions of the work of Foucault (see, for example, Siebert \& Walsh, 2013). Section six offers some concluding observations.

\section{Virtue Ethics, Leadership and Management Education}

Any discussion of virtue ethics and leadership in the business and management literatures faces the task of identifying a site from which to commence its deliberations. A convenient point of departure is the text for business ethics utilized by the authors in their teaching, namely Dirk Crane and Andrew Matten's (2010) Business Ethics. As with similar texts (see, for example, Scarlet, 2014, pp. 12-16; Grace \& Cohen, 2013, pp. 11-24) virtue ethics is introduced as one point of a central, tripartite framework for comprehending ethical theory. This framework is comprised of, first, 'consequentialist' theory, or consequentialism as a system of belief practices, exemplified by both egoism (self-centred ethical reasoning) and utilitarianism ('the greatest happiness for the greatest number') and accompanying theoretical extrapolations. The second point of the broad framework is 'deontological' ethical theorizing, which is defined as being non-teleological (i.e.: not ends-based) and is exemplified contemporaneously in rights-based theories of justice and historically by the 'categorical imperative' developed by Immanuel Kant.

These first two points in the tripartite framework are frequently juxtaposed against one another. It is the third, namely virtue ethics and its place in management education broadly conceived, that is our direct concern here. According to Crane and Matten (2010, pp. 118-119) virtue ethics has three defining characteristics. First, morally correct actions are those undertaken by people with virtuous characters. Therefore, the formation of a virtuous character is the first step toward morally virtuous behaviour. Second, following Aristotle (2004) virtue ethics emphasizes two different types of virtues: moral (friendship, mercy, loyalty, etc.) and intellectual (wisdom, for example). Third, virtue ethics is a process of self-development through self-reflection: finding out what is virtuous, attaining this, and working on being virtuous defines the good life, at both individual and organizational levels.

This tripartite framework is useful as a heuristic toward understanding ethical theory at a rudimentary level. Yet one can juxtapose this simplified characterization of virtue ethics with a brief consideration of some contemporary scholarly writing on the subject and reflect upon the possibility of incorporating some of this more advanced work into business ethics teaching. A measure of the complexities accompanying the scholarship in this area of inquiry is evident in a recent 'Special Edition' of Journal of Business Ethics (JoBE) devoted to canvassing the topic 'Putting virtues into practice: A challenge for business and organisations'. The 'Special Edition' consisted of nine contributions. A brief exposition of just the first of these is indicative of the profound nature of conjecture and refutation associated with discussions of virtue, leadership and business/organizational theory and practice, particularly in a management education setting.

In their paper 'In search of virtue: the role of virtues, values and character in ethical decision making' Crossan, Mazutis and Seijts (2013a) addressed the nub of our discussion here, asserting that 'business schools [are expected] to take a leadership role in helping [students] understand what character is, to identify what impact it has on decision making, and how it can be developed' (Crossan et al., 2013a, p. 568). In their critical examination of descriptive theories of ethical decision-making, or what the authors' referred to as 'Ethical Decision-Making (EDM) models', they observed that 'Descriptive ethicists ... largely avoid applying any manner of normative content when discussing intrinsically normative questions such as the processes of EDM' (Crossan et al., 2013a, p. 569; emphasis added).

To counter this tendency, Crossan et al. (2013a) constructed a list of what they labelled 'Virtuous Behaviour Orientations' (VBOs) grounded in the relationships between character traits and Aristotle's idea of the 'virtuous mean'. The most striking feature of this list is decidedly not the putting forward of concepts associated with the 'virtuous mean', such as 'creativity', 'curiosity', 'open-mindedness' and 'love of learning' with respect to the virtue of wisdom, for example. Rather, it is the inclusion of traits exhibiting both a deficiency in wisdom ('unoriginality', 'close-mindedness' and 'apathy', for example) as well as those with an excess thereof ('impracticality', 'obsession' and 'lack of judgement') (Crossan et al., 2013a, p. 574). A consideration of these concepts is far removed from 'textbook' understanding of ethics as we have them depicted here. Yet if we accept the idea of the virtuous self as important, the teaching of these more nuanced understandings of virtue-and vice -has to be countenanced. 


\section{Approaches to Learning: Virtue Ethics as the 'Ghost in the Machine'}

Revisiting the management education literature with an eye for virtue ethics, it is not difficult to ascertain the importance of the idea, albeit in nascent form. The key issue for educators, particularly in an online context, has centred on what teaching and learning practices result in transformational change for the student derived from experiential learning. For example, Mintzberg (2004) argued that any skills of effective management can only be learned from personal experience. Similarly, Kolb (1984) discussed 'experiential learning'. Navarro (2008) suggested that one of the six key elements of an ideal MBA ought to be 'experiential learning'. Baden and Parkes (2013, p. 296) have recently argued that if business education wishes to develop future business leaders with a greater knowledge of social responsibility, sustainability, and ethical practice, programs need to consider the role that 'experiential learning' can play.

These contemporary discussions reflect earlier work. For example, Kolb $(1984$, p. 41) defined experiential learning as 'the process whereby knowledge is created through the transformation of experience [where] knowledge results from the combination of grasping and transforming experience'. Kolb's (1984) ensuing model comprises four key elements: concrete experience; observation and reflection; formation of abstract concepts and testing in new situations. The model suggests that individuals learn best when they participate in a concrete experience followed by reflecting on that experience in order to better process or construct knowledge. Types of experiential learning in the educational context can include group-based exercises or projects; internships; role playing; mentoring; job shadowing; on-the-job assignments; simulations; or service learning (i.e.: volunteering with a not-for-profit organisation). Astin (1984) argued that experiential learning, combining theory and practice, service learning, collaboration, and reflection increases a student's ability to learn by requiring more energy investment by the student. In a similar vein Astin's (1984) suggested the greater the personal investment students make in their education, the greater their personal and educational development will be. Weber and Sleeper (2003) argued that experiential learning activities such as service learning can help students develop their personal skills, interpersonal and communication skills, team work, decision-making and leadership skills. In all of these accounts of optimal management education, engagement with concrete examples and critical reflections upon these experiences combine to inform not only future practice but also self-development; a close proxy to how we have defined the development of virtue in our discussion here.

Waddock and Lozano (2013) recently made a compelling case for a different kind of management and leadership education that focuses on the development of reflective practice for increasing self-awareness, to create the will to lead and manage with a focus on both 'soul' and 'heart'. These qualities are perceived to be essential for leadership that has a well-defined social conscience to create the kind of work place where people can thrive as human beings (Waddock \& Lozano, 2013, p. 267). It is argued that understanding of self is critical to the development of leadership character (Crossan et al., 2013b; Waddock \& Lozano, 2013).

Thus a key element of experiential learning is for students to engage in self-reflection. This is often linked to the notion of transformative learning. Mezirow (2000) defined transformative learning as an individual engaging in critical self-reflection about their deeply held assumptions and the validation of their beliefs, through the experiences and perceptions of others. Further, Mezirow (2000) argued that the competencies associated with transformative learning (such as becoming more open, reflective, inclusive, discriminating, and emotionally capable of change) have the potential to make students become better leaders and that transformative learning can assist in developing students as they are taught to understand and adopt ethical behaviours. This is supported by Taylor (2006) who argued that transformative learning can result in changes not only related to ways of thinking, but also to ways of being.

The teaching of virtue ethics brings together the concepts of experiential learning and transformative learning, as the social interactions from working in groups or with businesses (experiential learning) can help students undergo a change in their frames of reference (transformative learning). For example, Rossouw (2002) argued that virtue should be treated as an outcome of social interactions or practices, rather than intellectual deliberations, and suggested that business ethics courses should require students to socially interact with others in a business setting in order to develop students' virtues alongside behavioural and managerial skills. Fernando (2011) described a Business Ethics and Governance program in which students are required to complete a 'social innovation project' collaborating with businesses to develop and implement socially innovative ideas to address a previously unmet social need (see also Sims \& Felton, 2006). The evidence appears to be strong: learning through self-reflection ought to be an element in management education.

At various points in this literature, pedagogical tools for encouraging critical self-reflection are discussed. These tools include student autobiographies, reviewing personal leadership activities, keeping a journal 
(including blogging), reflecting on the leadership of others, reflecting on theoretical literature, paired or group discussion, self-reflective papers, and citing critical incidents (Dentsen \& Gray, 2001; Hiemstra, 2001; Roebuck et al., 2006; Scott, 2010). We now turn to how a particular tool has been deployed to foster the development of virtue ethics in the context of our program.

\section{An Online Leadership Development ePortfolio (LDE)}

Through the combination of admission criteria, curriculum, assessment methods and the requirement to complete an online Leadership Development ePortfolio (LDE) we argue that the online MBA which the authors teach into is making significant strides in facilitating the development of the virtuous self. This is made possible through a combination of experiential learning, social learning and reflective learning over the engagement in the program. Further, students are required to have at least three years work experience to draw from and to study while employed. The twelve-unit program comprises eight core and four elective units taught via the 'Moodle' learning Management System and emphasises the development of ethical and self-awareness through subjects such as 'Business Ethics, CSR and Sustainability', 'Managerial Thinking and Decision Making', 'Processes of Management and Organisational Behaviour', along with more technical knowledge in accounting, finance and economics. Students engage in social learning online through discussion boards and group work.

Prima facie the overall form and content of our MBA may resemble similar programs. However, a key dimension of this particular program is the requirement of an ePortfolio. An ePortfolio can be oriented toward employability and lifelong learning. For example, several scholars have suggested that it also has the potential to achieve a deeper learning, exploring the values of the participants as whole human beings operating from a places of integrity: 'The best portfolios offer an integrated representation of what an individual knows, has learned and can practice and maps the relationship between personal, academic and professional identities ... for richer learning and more powerful relationship' (Cambridge, 2008, p. 254; see also Peet et al., 2011). A key way to link those experiences is through reflective practice that integrates the learning journey with students' career and broader life experience, often stored in the form of a blog.

The critical question at this juncture is the extent to which such a tool can be qualitatively assessed as developing virtue, rather than encouraging mere introspection or ethical solipsism. Several authors have addressed this question. For example, Grant (2009) suggested that in order to encourage students to behave more ethically attention must be focused on people's identities and values since much of our codified ethics are underpinned by those values. More specifically, Grant and Grant (2006) have argued that values help us define what we regard as the good; they help us to map an ethical course in life and they facilitate a reflective process through which we can develop a sense of our identity and an idea of the self we are striving to be. For these reasons the role of ePortfolios in ethical development relies at least partially on the functionality of the software that allows for temporal engagement over the life of one's study - reflections can be accessed at a later date. Arguably, the event of recording one's values explicitly will at least raise awareness of how these values are being challenged (Grant $\&$ Grant, 2006). This space for ethical development conforms to Foucault's view in his later work writ large, that ethics is not about universal moral laws that must be obeyed; nor is it concerned with action directed by a focus on consequentialist calculations.

In our program, students are initially provided with information about how to initialise their ePortfolio using designated portfolio software. The software plug-in allows for storage of documents, blogging, sharing of information and social networking with other students. Students are also sent a complimentary text on leadership (Dalglish \& Miller, 2010) and encouraged to work their way through it in the course of the MBA, starting with the chapter dealing with self-awareness. They are also asked to reflect on their strengths and weaknesses as a manager and to identify face-to-face learning opportunities to redress their weak points. This might involve seeking a mentor, engaging a coach, attending training on public speaking or negotiation or other relevant activities. The underpinning idea is that in an online program with no compulsory face-to-face attendance requirements, opportunities do not exist to develop those sorts of skills through classroom interaction.

Additionally, students are asked to engage in 20 hours of community service, a requirement informed by the literature on service learning (for example, Godfrey, 1999). This assumes that significant and important learning takes place through the integrated combination of abstract conceptualization and concrete experience, coupled with reflection on experience. Service learning in management education promotes what Godfrey (1999) described as 'moral management', which reminds managers that they hold great authority and responsibility over economic and social resources and that part of this responsibility includes addressing and working on social problems. Engaging in service learning can help to develop moral imagination, though this can be difficult to measure (Bernacki \& Jaeger, 2008). 
The submitted ePortfolio consists of copies of the evidence of the face-to-face professional development activities and the community service component, together with a 2000 word summary of students' reflections on their coursework and face-to-face learnings over the life of the program. This can be done through the ePortfolio software or by submitting the documents by email. While the documenting of work and experience is a useful archival tool, the strategic outcome of the program is that the full impact of ePortfolios is realized when the author(s) and others reflect on the content (Reese \& Levy, 2009). Such reflection can be undertaken in many forms and the program encourages students to use whichever media works best for them. As the cohort of students who commenced with the ePortfolio begins to graduate, we are able to assess the effectiveness of the current model. Feedback from students through their reflective summaries has indicated that the requirement to complete the LDE has been a positive contributor to their experience, deepening the learning.

Nevertheless, we have sensed that there are elements of the program that could be improved. For example, a key limitation of the current model is that it is assessed only at the end of the MBA Program, making it possible that the 2000 word summary of reflections may only be written as a conclusion to the program rather than being drawn from reflections across the journey. Given the identified benefits of reflective practice, this is an aspect of the current model that needs to be addressed. The other major limitation is a lack of engagement with the portfolio-specific software, which many students have found cumbersome to use. Many have opted to reflect in a document and to record their evidence of face-to-face activities on their computer. The benefit of using portfolio software resides in its capacity to allow group discussions and the subsequent sharing of insights with fellow students, prospective employers and the general public. However, we have recognised that the software should not impede the goals of the exercise by being difficult to use. In addition, at this point the portfolio-specific information is not available after graduation. Thus any documents or blogs cannot be accessed as part of ongoing professional networking and development. This limitation renders it a less attractive option than, perhaps, something more easily accessible and open such as Google Docs. In future iterations, a more scaffolded approach that provides the student with online tools to facilitate leadership development and a more open platform connected to the social media tools they use professionally may be of greater benefit to students through their learning journey and beyond (Zhang, Olfinan, \& Ractham, 2007).

\section{Criticisms and Directions for Future Refinement}

The aforementioned limitations may not be the only ones, or the most significant. The efficacy of such a program lies in the capacity of the student to reflect honestly about themselves, about their management and leadership practices, about the theories they are applying to their workplace through their assessment tasks and record those reflections fearlessly. For example, Siebert and Walsh (2013) have recently asked if required reflection in work-based learning or in the university context is merely a case of self-regulation rather than self-development. Arguments for the self-regulating effects of work-based learning through reflective practice draw on Foucault's work on governmentality and power, positing that the nature of the workplace might make reflection more about reinforcing complex existing power relations rather than providing someone with the freedom to create him or herself (Siebert \& Walsh, 2013). Further, in the university context students may feel the need to produce 'the right answer' and project an image that they think is acceptable to the assessor, thus the reflections may be self-censored (Siebert \& Walsh, 2013, p. 171). However, the same authors also argued that such criticisms are overly pessimistic and tend to emphasise totalising interpretations of power relations, assuming that the student is always repressed in the relationship with their employer or the academy, thereby causing them to construct themselves in a self-censorial way (Siebert \& Walsh, 2013). This latter argument recognises that if one has complete power over the other there are no relations, only domination: 'Thus in order for power relations to come into play there must be at least a certain degree of freedom on both sides' (Foucault, 1997, pp. 291-292).

Siebert and Walsh (2013, p. 172) explored this argument and suggested that freedom and power relations play out through discursive practices that are underpinned by the participants. Such assumptions have been referred to as 'theories in use' (Argyris \& Schon, 1974), 'mental models' (Senge, 1990) and 'frames' (Lakoff, 1996 \& 2005). Reflective practice can make one aware of those unconscious ways of viewing the world and open up one's perspective to other possibilities. They can also make one aware of the theories in use set against the theories espoused by organisations, where rhetorical commitments such as being family friendly are made but where staff work extended unpaid hours regularly: the active engagement with the discourses in the workplace and in an organisation provides freedom to respond to those discourses in a variety of ways as participants reflect on themselves and their own values and work towards self-mastery.

Foucault (1997) contended that freedom is expressed in the practices of 'the care for self' that enable a person to appreciate and exercise their relations with others so that they do not seek to dominate others. Further, according to Foucault, self-mastery is the ethic of the self encountered in Ancient Greece, that witnessed the development 
of an ethos of the self: 'Extensive work by the self on the self is required for this practice of freedom to take shape in an ethos that is good, beautiful, honourable, estimable, memorable and exemplary' (Foucault, 1997, p. 286). The care for the self also extends to care for others in one's dealings with them, requiring self-knowledge as well as knowledge of what is acceptable conduct. A student actively engaged in reflective practice throughout their learning journey has a great opportunity to work toward self-mastery as expressed in the 'Virtuous Behaviour Orientations' (Crossan et al., 2013a) that express Aristotle's virtuous mean. Our challenge is to provide the opportunities for the depth and breadth of reflection that will assist our students to move towards self-mastery.

\section{Conclusion}

While the continued development of the Leadership Development ePortfolio as an element to our MBA program will principally be explored and implemented in consultation with the participants, the literature suggests some potential channels for this development. For instance, Blasco (2012, p. 369) has recently argued that in order to encourage critical reflection, teachers require knowledge about their students' 'frames of reference', so that they can build on or challenge those frames. Glisczinski (2007) (cited in Blasco, 2012, p. 381) suggested that teachers should assess students' dispositions as learners, prior to, during and after the learning process, using a descriptive instrument. Rusch and Brunner (2013, p. 45) found that experiential learning 'disrupts a carefully crafted student identity', and that whilst the experience is supported by enhanced knowledge of the learning self, the facilitated reflection can lead to a significant shift in both learner and leader identity. They also found that equipping students with advanced knowledge of approaches to learning led to deeper and transformative insights about learner and leader behaviour.

We need to be mindful of the criticisms articulated by Siebert and Walsh (2013), namely that reflective practice in work-based learning are potentially problematic because of the complex interplay of power relationships students experience which might encourage self-censorship to conform to expected norms. Thus, we need to work to ensure that students feel secure enough to be honest. This poses questions for us in developing programs and assessment tasks where students (who previously did not know each other) are required to come together in forums (whether online or face-to-face) to share ideas, collaborate and interact in a learning community, whether that community is a Learning Management System or an online portfolio platform.

Challenges exist in the online space regarding forms of experiential learning that can facilitate self-awareness and the development of virtue. These observations speak to the way individuals prefer to engage in learning and pose a question regarding how far the online space can be utilised for the development of leadership and management capabilities. This is an issue that needs to be further evaluated in the context of (for example) age groups and familiarity with and expectations of online learning. A case can be made that when any individual embarks on a personal learning journey they have a number of people they can interact with on a daily basis, not connected directly to their learning, who can provide a living laboratory for practice, reflection and engagement with development principles, theories and practices. The Leadership Development ePortfolio developed by the authors endeavours to capitalise on the learning that these relationships offer through the requirement to develop a reflective practice throughout the MBA program.

One thing is clear: early reports from students who have completed this particular element of the MBA program endorse the decision to make this a mandatory requirement. While it remains to be seen how significant the impact is on the development of virtuous, ethical and sustainable leadership qualities in our student cohorts, the outcomes to date strongly support the notion that scaffolding a reflective practice as an intrinsic component of the online learning experience is a major contribution to the development of the virtuous self in the virtual domain.

While this paper has surveyed the literature and reflected upon our own practices in online management education, as a check against these practices conforming to the mere self-regulation identified by Siebert and Walsh (2013), monitoring and evaluation could also derive from cohorts of students across similar programs, thereby providing more robust evidence alongside the qualitative material derived from individual programs.

\section{References}

Argyris, C., \& Schön, D. (1974). Theory in practice: Increasing professional effectiveness. San Francisco: Jossey-Bass.

Aristotle. (2004). In F. H. Peters (Ed.), Nicomachean ethics. New York: Barnes and Noble.

Astin, A. (1984). Student involvement: A developmental theory for higher education. Journal of College Student Development, 40, 518-529. 
Baden, D., \& Parkes, C. (2013). Experiential learning: Inspiring the business leaders of tomorrow. Journal of Management Development, 32, 295-308. http://dx.doi.org/10.1108/02621711311318283

Bernacki, M. L., \& Jaeger, E. (2008). Exploring the impact of service-learning on moral development and moral orientation. Michigan Journal of Community Service Learning, 5-15.

Blasco, M. (2012). Aligning the hidden curriculum of management education with PRME: An inquiry-based framework. Journal of Management Education, 36, 364-388. http://dx.doi.org/10.1177/1052562911420213

Cambridge, D. (2008). Layering networked and symphonic selves. A critical role for ePortfolios in employability through integrative learning. Campus-Wide Information Systems, 25(4), 244-262. http://dx.doi.org/10.1108/10650740810900685

Crane, D., \& Matten, A. (2010). Business Ethics. Oxford: Oxford University Press.

Crossan, M., Mazutis D., \& Seijts, G. (2013a). In search of virtue: The role of virtues, values and character in ethical decision-making. Journal of Business Ethics, 113, 567-581. http://dx.doi.org/10.1007/s10551-013-1680-8

Crossan, M., Mazutis, D. S., \& Ganz, J. (2013b). Developing Leadership Character in Business Programs. Academy of Management Learning \& Education, 12, 285-305. http://dx.doi.org/10.5465/amle.2011.0024A

Dalglish, C., \& Miller, P. (2010). Leadership-understanding its global impact. Prahran: Tilde University Press.

Dentsen, I., \& Gray, J. (2001). Leadership development and reflection: What is the connection? The $\begin{array}{lllll}\text { International Journal of Educational } & \text { Management, } & 15,\end{array}$ http://dx.doi.org/10.1108/09513540110384466

Fernando, M. (2011). A social innovation based transformative learning approach to teaching business ethics. Journal of Business Ethics Education, 8, 119-138. http://dx.doi.org/10.5465/AMLE.2006.22697016

Fontordona, J., Sison, A. J. G., \& De Bruin, B. (2013). Editorial introduction: Putting virtues into practice: A challenge for business and organisations. Journal of Business Ethics 113, 563-565. http://dx.doi.org/10.1007/s10551-013-1679-1

Foucault, M. (1997). The ethics of the concern for the self as a practice of freedom. In Rabinow, P. (Ed.), Michael Foucault: Ethics. The essential works (volume 1). London: The Penguin Press.

Glisczinski, D. (2007). Transformative higher education: A meaningful degree of understanding. Journal of Transformative Education, 5, 317-328. http://dx.doi.org/10.1177/1541344607312838

Godfrey, P. C. (1999). Service-learning and management education: A call to action. Journal of Management Inquiry, 8, 363-378. http://dx.doi.org/10.1177/105649269984004

Grace, D., \& Cohen, S. (2013). Business Ethics (5th ed.). Oxford: Melbourne.

Grant, S. (2009). Electronic Portfolios. Personal information, personal development and personal values. Oxford: Chandos Publishing.

Grant, S., \& Grant, A. (2006). Ethical portfolios: supporting identities and values. Paper presented at the ePortfolio 2006, Oxford.

Hiemstra, R. (2001). Uses and benefits of journal writing. New Directions for Adult and Continuing Education, 90, 19-26. http://dx.doi.org/10.1002/ace.17

Kolb, D. (1984). Experiential learning. Englewood Cliffs, NJ: Prentice-Hall.

Lakoff, G. (1996). Moral politics. What conservatives know that liberals don't. Chicago: University of Chicago Press.

Lakoff, G. (2005). Don't think of an elephant. Know your values and frame the debate. Melbourne: Scribe.

Mezirow, J. (2000). Learning as transformation: Critical perspectives on a theory in progress. San Francisco: Jossey-Bass.

Mintzberg, H. (2004). Managers not MBAs: A hard look at the soft practice of managing and management development. San Francisco: Berrett-Koehler.

Navarro, P. (2008). The MBA core curricula of top-ranked US business schools: A study in failure? Academy of Management Learning and Education, 7, 108-123. http://dx.doi.org/10.5465/AMLE.2008.31413868

Reese, M., \& Levy, R. (2009). Assessing the future: E-Portfolio trends, uses, and options in higher education. 
Educause Center for Applied Research- Research Bulletin, (4).

Roebuck. D., Stigler, T., \& Tyran, K. (2006). Through the looking glass: Using reflection in management education. Journal of the Academy of Business Education, 6, 52-62.

Rossi, P. G., Magnoler, P., \& Giannandrea, L. (2008). From an e-portfolio model to e-portfolio practices: Some $\begin{array}{llll}\text { guidelines. } & \text { Campus-Wide } & \text { Information 219-2. }\end{array}$ http://dx.doi.org/10.1108/10650740810900667

Rossouw, G. (2002). Three approaches to teaching business ethics. Teaching Business Ethics, 6, 411-433.

Rusch, E., \& Brunner, C. (2013). Transforming leadership identity in a virtual environment: Learning about the leading self. Journal of Transformative Education, 11, 45-69. http://dx.doi.org/10.1177/1541344613489351

Scarlet, S. (2014). Markets, ethics and business ethics. Sydney: Pearson.

Schon, D. A. (1987). Educating the reflective practitioner: Toward a new design for teaching and learning in the professions. San Francisco: Jossey-Bass.

Scott, S. (2010). Enhancing reflection skills through learning portfolios: An empirical test. Journal of Management Education, 34, 430-457. http://dx.doi.org/10.1177/1052562909351144

Senge, P. (1990). The fifth discipline. The art and practice of the learning organisation. London: Random House.

Siebert, S., \& Walsh, A. (2013). Reflection in work-based learning: Self-reflection or self-liberation? Teaching in Higher Education, 18, 167-178. http://dx.doi.org/10.1080/13562517.2012.696539

Sims, R., \& Felton, J. (2006). Designing and delivering business ethics teaching and learning. Journal of Business Ethics, 63, 297-312. http://dx.doi.org/10.1007/s10551-005-3562-1

Taylor, E. (2006). A critical review of the empirical research of transformative learning (1999-2005). Paper presented at the 47th annual Adult Education Research conference (AERC), Minneapolis, Mn.

UN (United Nations). (2010). Principles for Responsible Management Education (PRiME). Retrieved from http://www.unprme.org/

Waddock, S., \& Lozano, J. M. (2013). Developing more holistic management education: Lessons learned from two programs. Academy of Management Learning \& Education, 12, 265-284. http://dx.doi.org/10.5465/amle.2012.0002

Waples, E., Antes, A., Murphy, S., Connelly, S., \& Mumford, M. (2009). A meta-analytic investigation of business ethics education instruction. Journal of Business Ethics, 87, 133-151. http://dx.doi.org/10.1007/s10551-008-9875-0

Weber, P., \& Sleeper, B. (2003). Enriching student experiences: Multidisciplinary experiences in service-learning. Teaching Business Ethics, 7, 417-435.

Woodley, C., \& Sims, R. (2011). EPortfolios, professional development and employability: Some student $\begin{array}{llll}\text { perceptions. } \quad \text { Campus-Wide Information } & \text { Systems, } & \text { 28(3), } & \text { 164-174. }\end{array}$ http://dx.doi.org/10.1108/10650741111145698

Zhang, S. X., Olfman, L., \& Ractham, P. (2007). Designing ePortfolio 2.0: Integrating and coordinating Web 2.0 services with ePortfolio systems for enhancing user's learning. Journal of Information Systems Education, Summer, 203-214.

\section{Copyrights}

Copyright for this article is retained by the author(s), with first publication rights granted to the journal.

This is an open-access article distributed under the terms and conditions of the Creative Commons Attribution license (http://creativecommons.org/licenses/by/3.0/). 